Article

\title{
Democracy or Oligarchy? Unequal Representation of Income Groups in European Institutions
}

\author{
Zoe Lefkofridi ${ }^{1, *}$ and Nathalie Giger ${ }^{2}$ \\ ${ }^{1}$ Department of Political Science, University of Salzburg, 5020 Salzburg, Austria; E-Mail: zoe.lefkofridi@sbg.ac.at \\ 2 Department of Political Science and International Relations, University of Geneva, 1211 Geneva, Switzerland; \\ E-Mail: Nathalie.giger@unige.ch \\ * Corresponding author
}

Submitted: 30 September 2019 | Accepted: 7 January 2020 | Published: 13 February 2020

\begin{abstract}
In this study we examine the representation of income groups in two EU-level institutions, the Council and the European Parliament. We find that the political positions of these institutions, and especially of the Council, are always on the right compared to European citizens, though closer to the wealthy among them. However, a more systematic analysis of congruence between different income groups and the Council reveals that while the poor are systematically underrepresented, the rich are not systematically over-represented. This holds both when we examine the poor and the rich across the EU as a whole and when we cluster them according to their respective member states.
\end{abstract}

\section{Keywords}

congruence; Council of the European Union; European Parliament; European Union; inequality; representation

\section{Issue}

This article is part of the issue "Political Behavior in the EU Multi-Level System" edited by Daniela Braun (LMU Munich, Germany), Martin Gross (LMU Munich, Germany) and Berthold Rittberger (LMU Munich, Germany).

(C) 2020 by the authors; licensee Cogitatio (Lisbon, Portugal). This article is licensed under a Creative Commons Attribution 4.0 International License (CC BY).

\section{Introduction}

At the core of any political regime stands the relationship between political and economic power. In Aristotle's Politics, the pioneering comparative study of political systems, Aristotle (384-322 BC) observed that an Athenian citizen under a democratic regime would not classify as such under an oligarchic regime and that the key difference between democracy and oligarchy was poverty and wealth (Aristotle's Politics, 1280a, as translated by Moschovis, 1989). Aristotle considered both democracy and oligarchy to be 'corrupt' regimes since neither served the preferences and interests of the whole society: While the poor dominated in democracy, oligarchy served only the interests of the wealthy. For this reason, in Aristotle's view, power should lie with the middle class. In contemporary representative government, citizens' views and opinions are channeled through professional party politicians who are expected to represent them and voice their concerns to various political institutions. This type of regime does not allow for the direct participation of citizens in political decision-making, and hence it is impossible for the poor to dominate. What about the wealthy, however?

Under representative government, the ballot concerns a choice between predefined policy directions, and in theory everybody's ballot has equal weight irrespective of income, and representatives should consider all citizens' preferences equally. However, there are reasons why representatives might neglect the views of the poor and/or cater to the rich. To begin with, deputies by definition do not belong to the lowest social strata; quite the contrary, as being a deputy comes with several economic and political privileges. Since the poor tend to turn out to vote in smaller numbers (Gallego, 2007; Lijphart, 1997), moreover, their limited participation may affect the outcome in ways disadvantageous for them. Furthermore, income may play a role in stages 
of the political process preceding or following the ballot: For instance, the rich can influence the policy agenda and direction through legal and/or illegal means such as the financing of party campaigns, or attempts to corrupt party politicians (see, for example, Rosset, Giger, \& Bernauer, 2013). Alternatively, the rich can block policymaking that threatens their interests; for example, big businesses faced with increases in taxes or wages may threaten to relocate production to countries with cheaper labor and lower taxes.

This raises the question of whether and to what extent the poor are well represented by contemporary democratic political institutions, especially in comparison to the rich. A growing literature on unequal representation of income groups in the US documents that citizens from the poorer income strata are less well represented and their voices less likely to be heard by US politicians (Bartels, 2008; Gilens, 2005; Kelly \& Enns, 2010; Soroka \& Wlezien, 2008; Ura \& Ellis, 2008). Recent research on unequal representation in a large number of European countries finds similar trends (e.g., Donnelly \& Lefkofridi, 2014; Giger, Rosset, \& Bernauer, 2012).

A large majority of these European countries are members of the EU, however, and in such a multilevel polity as the EU wealthy citizens may have more influence over policy simply because they have more resources to invest in lobbying actors at different levels of governance, including not only national political party organizations and national governments but also EU institutions. Surprisingly, however, very little is known about unequal representation at EU level. Studies on EU representation have focused quite narrowly on the European Parliament (EP) and have largely neglected the Council (though, see Hagemann, Hobolt, \& Wratil, 2017). We argue that this is an unsatisfactory state of the art and that we need to compare and contrast potentially unequal representation in the EP to the same phenomenon in its counterpart, i.e., the Council.

Ignoring the question of unequal representation at EU level is highly problematic for several reasons. From the outset the EU promoted economic integration among European states, including the opening of borders, market liberalization, and economic competition, which in turn has created new cleavages of winners and losers within European publics, i.e., between those able to engage in and benefit from these processes and those who cannot (Kriesi et al., 2006; see also Fligstein, 2008). Economic integration has additionally exacerbated income inequality within member states by impacting their welfare states and by undermining the position of labor through the pressures of international wage and employment competition (Beckfield, 2006). At the peak of the Great Recession in 2008, the direction of the EU's economic policy decided on by the Council (i.e., austerity, including budget and wage cuts) tended to hurt middle- and low-income citizens rather than the wealthy across the EU. Thus, unequal representation may also concern specific income groups within member states and/or across the EU.
The question thus arises as to whether EU institutions represent poor Europeans less well than they represent the rich. In this article we tackle this question by examining the two major channels of representation in policy-making at EU level, using empirical evidence regarding the unequal representation of income groups. On the one hand, the EP is the only EU-level body whose composition can be determined directly by the European people and the only supranational institution with a clear mandate of citizen representation; it is also the only supranational institution where citizens' representatives sit according to party-ideological rather than national/territorial lines.

On the other hand, the Council brings together 'sovereigns.' In fact, there are two types of Council. First there is the European Council, which is the top-level political configuration of heads of states and governments of the EU member states and which defines the most important policy issues and determines the political direction of the entire Union. Second, there is the Council of Ministers, which meets for the purpose of legislation in ten different policy-related configurations of the $28 \mathrm{~min}$ istries of the member states. Here we treat both as a 'unified' political body of the Union, hereafter referred to as the 'Council' or 'EU Council,' since individual Council members, whether they be presidents, prime ministers or ministers, enjoy territorially-bound democratic legitimacy for their actions. Scrutinizing the Council is particularly important given that, prior to the Lisbon Treaty of 2007, the Council was the main legislator with the highest decision-making competences.

This study contributes to the scant literature analyzing the EU Council in terms of political representation (Hagemann et al., 2017) and is the first to examine the unequal representation of income groups in EU institutions. In pursuit of these goals, we study the degree of ideological congruence, which is a very useful indicator of alignment between publics and policymakers. Congruence constitutes an important prerequisite for citizens' 'substantive' representation in the policymaking process (Mansbridge, 2009; Pitkin, 1967): If publics and their representatives diverge greatly, it is unlikely that the latter will include the public in policy-making processes. In this study we examine the ideological congruence between poor and rich Europeans with regard to two key EU institutions over a ten-year period. We are thus able to uncover important facets of representation and to document for the first time the degree of inequality that exists in representing citizens at EU level.

\section{Citizens' Representation at EU level}

Thomassen and Schmitt (1997; Schmitt \& Thomassen, 1999) have long argued for a distinction to be drawn between two different channels of representation of citizens' preferences at EU level. There is one direct channel of influence via the EP, which operates through the selection of (national) party candidates to represent citizens 
in the Parliament. The second channel is indirect and operates through the participation of national governments in the EU Council. While this distinction is widely recognized, empirical research has fallen short in analyzing these two channels of representation simultaneously. In fact, empirical research on the topic has mainly focused on representation via the direct channel of the EP (see, for example, Lefkofridi, 2020; Costello, Thomassen, \& Rosema, 2012; Lefkofridi \& Katsanidou, 2014; Mattila \& Raunio, 2012). These studies generally suggest that EP representation works quite well on the left-right dimension but less well for European integration-related topics (see, for example, Costello et al., 2012). Research on the indirect channel is scarce, though a recent exception is Hagemann et al. (2017), who show that decision-making in the Council is influenced by citizens' opinions: For example, when domestic electorates are skeptical about the EU their governments are more likely to oppose legislation aimed at deepening European integration. On the other hand, Alexandrova, Rasmussen, and Toshkov (2016) have shown how citizens' priorities play a role in determining the amount of attention certain topics are given by the Council.

To date, however, no study has examined whether representation is equally good for different societal groups, e.g., differentiated by income. This is quite remarkable given that several strands of research suggest economic and political inequality to be related to each other (e.g., Lefkofridi, Giger, \& Kissau, 2012). First, the significant negative effect of income inequality on turnout is consistent both across and within countries (Schäfer \& Schwander, 2019). Moreover, the poor participate less in democratic elections at both national and European levels (Gallego, 2015; Mattila, 2003). One reason why the poor tend to participate less in democratic elections is the well-established relationship between income and education, which in turn impacts upon political knowledge. In such a complex multilevel and transnational system of governance as the EU, political knowledge has been shown to matter in regard to turning out to vote in European elections (Braun \& Tausendpfund, 2019).

Second, research on representation shows that the poor are not well represented in either the US or in Europe. Studies that have examined responsiveness in the US, (i.e., focusing on the question of how citizens' preferences are mirrored in public policy) have found that when the preferences of rich and poor diverge, the views of the affluent will count more (e.g., Bartels, 2008; Gilens, 2012; Gilens \& Page, 2014). This holds also for the subnational level (see, for example, Flavin, 2012). Similar findings emerge from studies focusing on a diverse set of European countries, including relatively developed and rich states such as Sweden (Persson \& Gilljam, 2019), Germany (Elsässer, Hense, \& Schäfer, 2017) and the Netherlands (Schakel, 2019). Besides these case studies, comparative research has also revealed that congruence between citizens and policymakers is often tilted towards the more affluent in
European societies (e.g., Peters \& Ensink, 2015; Rosset et al., 2013; Schakel \& Hakhverdian, 2018). On the basis of national-level evidence from both sides of the Atlantic, therefore, unequal representation seems to be a widespread phenomenon.

These findings beg the question of whether and to what extent a similar phenomenon is present when it comes to the representation of less affluent citizens at EU level. The mechanisms that drive unequal representation listed in the current literature, e.g., the poorer strata turning out in lower percentages or the more affluent using their financial means to influence policy via campaign donation or lobbying, seem equally relevant at EU level as they are at the national level. Accordingly, we aim to fill this research gap by examining how unequal income groups are represented both by the EP and by the EU Council.

\section{Research Design}

In order to tackle the general question of the potentially unequal representation of citizens' preferences by EU institutions, we proceed in two steps. Our first goal is to trace the evolution of the income groups' positions over time and examine their congruence with the two key institutions. In the context of political representation, the term 'congruence' (which connotes agreement, harmony, or compatibility between two entities) is a criterion for assessing whether representation works (Lefkofridi, in press), since comparing citizens' opinions with the opinions of those who make policy on their behalf helps assess the 'democratic' character of political representation (Rohrschneider \& Whitefield, 2012, p. 87). In this step of the analysis, we study income group representation at the level of the EU-wide citizenry who are affected by the decisions made by the Council and the EP. To be clear, if the preferences of the poor and the rich do not differ, then even if representatives disregard the poor there is no problem regarding democratic representation. However, research shows that on many issues, and especially on the issue of economic redistribution, the preferences of the poor and the rich differ systematically (e.g., Donnelly \& Lefkofridi, 2014; Giger et al., 2012), at least at national level.

Our second goal is to take a closer look at the Council, which represents citizens clustered in member states. In essence, the Council as a whole can be conceived of as a political body in which representatives of all member states come together to decide about common policy for the EU as a whole while at the same time seeking to ensure that domestic preferences are promoted (or at the very least do not jeopardize those preferences). Conceived thus, each member of the Council would make efforts not to diverge from the position of their national constituency. However, the ways in which domestic preferences are defined differ according to the ideological composition of the government in place-and some governments may be closer to the poor/rich within 
their national constituencies. Considering this additional type of congruence not only helps to answer questions about national-territorial representation in the Council, i.e., of each member state separately, but also helps us to ascertain whether the EU-wide pattern regarding the representation of the poor/rich also holds if we disaggregate the EU into its members. This step helps examine whether the findings based on the aggregate picture are replicated at member-state level and ensures that the EUwide pattern does not mask a skewed distribution of unequal representation.

To answer our research question, we use existing data gathered from both mass and elite levels. For citizens' positions we mainly use the European Social Survey covering the period 2002-2012 (European Social Survey, 2002-2016). More information on the development of mass political positions over time in the 26 member states covered by this study can be found in Supplementary File A. It should be noted that survey data is missing for Malta and Croatia. All the mass surveys have been weighted according to their population. For elites' positions, we use expert surveys: The Chapel Hill Expert Survey (CHES; Bakker et al., 2015) and the expert survey undertaken by Benoit and Laver (2006), as we will explain in more detail below.

Using these data sources, we focus on the left-right dimension of political conflict. The left-right heuristic is rooted in the French Revolution and summarizes divergent policy positions, providing an organizing principle for party competition and voting behaviour; albeit crude, the left-right dimension provides valuable information about the match between the represented and their representatives in terms of general ideological orientation and is thus particularly useful for comparative research (Lefkofridi, in press). When examining representation within the EU, however, there is also a second dimension of political contestation to consider, i.e., that of pro-/contra European integration (Mair \& Thomassen, 2010). Prior to the Eurozone crisis, it was mainly parties on the fringes that mobilized voters on the EU dimension (de Vries, 2007); European issues did not play a major role even in EP elections (Braun, Hutter, \& Kerscher, 2016; Lefkofridi \& Kritzinger, 2008). The salience of the EU dimension for EU-level party competition and citizens' representation increased in 2014 (see Lefkofridi \& Katsanidou, 2018). For most of the years covered by our study, therefore, the EU dimension was not as important as the left-right dimension in European elections, and even less important in national elections. Given that the Council's composition is the result of a series of national elections, the present study thus does not analyze this dimension. Besides, the EU question was not included in the European Social Survey.

Our analysis necessitates a summary measure of the Council's position, and for this purpose we rely on earlier work that uses a measure called the 'Center of Gravity' (CoG; Gross \& Sigelman, 1984; Manow \& Döring, 2008). The CoG is an aggregated position of national cab- inets. We calculate the CoG of the Council using information from two sources: national government compositions from the Parlgov website and party position data from expert surveys. We primarily used the CHES from Bakker et al. (2015), which has the advantage of timevariant party positions; in the case of Luxembourg, Malta, Cyprus, and Croatia, however, as well as a few single parties in other countries not covered by the CHES, we utilized the Benoit and Laver (2006) expert survey instead. While the position of each government is the weighted average of all incumbent party positions, or in other words the CoG of national cabinets (see Supplementary File B for more information), the CoG of the Council is an aggregation of all member states' national government positions. For the descriptive figures and the subsequent regression analyses the data is presented in a monthly format, since the Council is subject to change when new national governments are formed. The position of the EP was measured with the same kind of data and is defined as the weighted average (by seats) of the parties present in the EP (with party positions based on data from CHES and Benoit and Laver [2006]). It can thus vary both according to election periods and enlargement rounds. This is relevant for the accession of Romania, Bulgaria, and Cyprus.

Ideological congruence is calculated as the distance between the left-right position of EU citizens belonging to different income groups and the CoG of the Council. As we are interested in the representation of sub-constituencies of the population (poor and rich), we have to measure congruence at individual level. Only in this way can we distinguish between citizens with high or low income. Individual congruence $C_{i j}$ is defined as the absolute distance between the position of a citizen $P_{-}$cit $_{i j}$ and the CoG of the Council CoG_council, times -1 . The multiplication by -1 allows for an easier interpretation of the results, as higher values indicate greater congruence.

$$
C_{i j}=-\left|C o G \_c o u n c i l-P \_c i t_{i j}\right|
$$

If the distance between a citizen and the government/party decreases, $C_{i j}$ rises from negative values towards 0 and ideological congruence increases. We use this individual level congruence measure to analyse both congruence across the EU as a whole and clustered in their respective national constituencies.

In doing so we follow recent developments in the study of congruence, especially the seminal work by Golder and Stramski (2010), who use a similar measure for studying national-level congruence. However, insofar as we differ methodologically from earlier work on representation in EU institutions, which has mainly used crosstabulations or factor models (e.g., Costello et al., 2012; Thomassen \& Schmitt, 1997), we cannot directly compare our results to those findings.

The population is split into three income groups, as is standard practice within this research field. Household income has been adjusted to household size (see Rosset 
\& Pontusson, 2014; Rueda \& Pontusson, 2010). The two lowest deciles of the income strata are classified as 'poor' while the two top deciles are classified as 'rich.'

As a first step, we thus present graphically the development of the ideological positions of our income groups and compare them to the ideological leanings of both the European Council and the EP. In a second step we regress income groups' positions on the CoG of the Council in a multilevel setting.

\section{Results}

We begin with a comparative picture of income group representation in the EP and the Council. Figure 1 shows an aggregate picture of how the positions of the Council and the EP evolved over time in the period 2000-2012 as compared to the positions of less and more affluent citizens across the EU (the income groups of all member states). In Figure 1 we see, first of all, that both the citizens (poor and rich) and the institutions (the EP and the Council) move around centrist (i.e., not extreme) positions, which is not surprising given that these are highly aggregated measures that tend to be very centrist. We also see that the poor are consistently positioned to the left of both the rich and the EU institutions (the EP and the Council). This indicates, in the first place, that the potential for unequal representation exists, since poor and rich citizens do not have identical preferences on the left-right dimension. These findings also echo other studies undertaken at national level in various European states (e.g., Giger et al., 2012). A third observation concerns the position of the rich as lying in-between the poor and the EU institutions. While the Council is systematically located further to the right of the citizenry, the EP overall seems to be more congruent with the citizenry (poor and rich). The Council moved to the left around 2007, which improved its congruence with the citizenry (the poor, but even more so the rich), but subsequently moved rightwards. The general picture, however, remains that the rich tend to be closer to both institutions' positions than the poor, which indicates that the representation of poorer citizens is worse than for those with higher income shares. We can only speculate how much these shifts are linked to the Great Recession, in regard to which some scholars (e.g., Lindvall, 2014) propose that there was first a shift to the right followed by a shift to the left.

Figure 2 focuses solely on the Council. Here we again examine the Council's representation of the poor and the rich but this time with income groups disaggregated into their respective national constituencies. Derived from data in Table 1, in technical terms Figure 2 displays the random slopes of the two individual-level predictors (high and low income) by country. In substantive terms it shows the degree of unequal representation of the poor and rich strata of society compared to the middle-income category. Negative coefficients signify worse representation, while positive numbers signify a closer match between the preferences of a group and the Council. In this figure we see that the poor are more likely to be underrepresented across member states: In 18 countries we see either a clear underrepresentation of their ideological preferences (e.g., in Cyprus and Romania) or no big differences between the representation of their ideological preferences and the preferences of the middleincome category (e.g., in France), while in only seven EU member states do the poor seem represented to a degree commensurate with middle-income voters (e.g.,

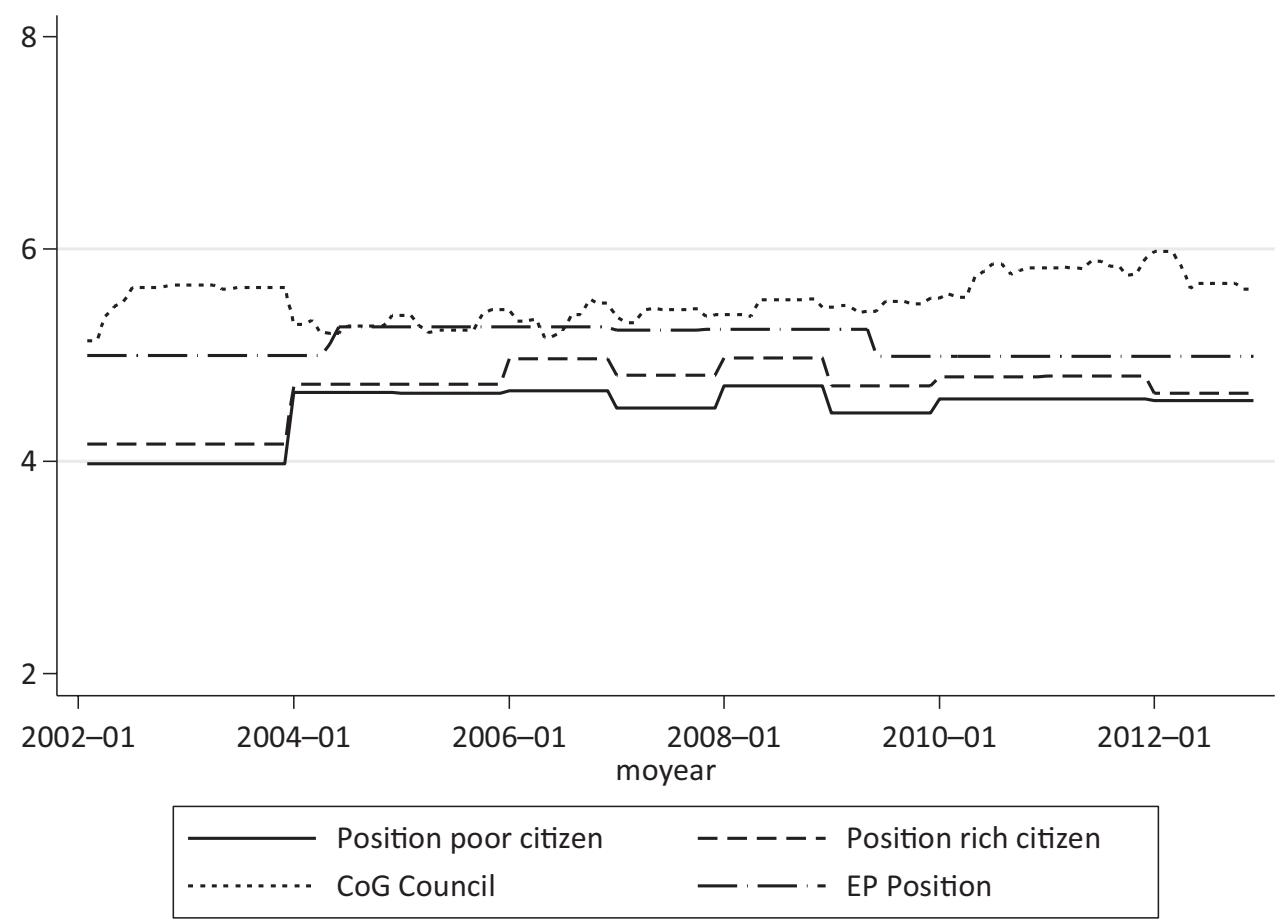

Figure 1. Congruence between the rich and poor and the EP and Council (across the EU). 


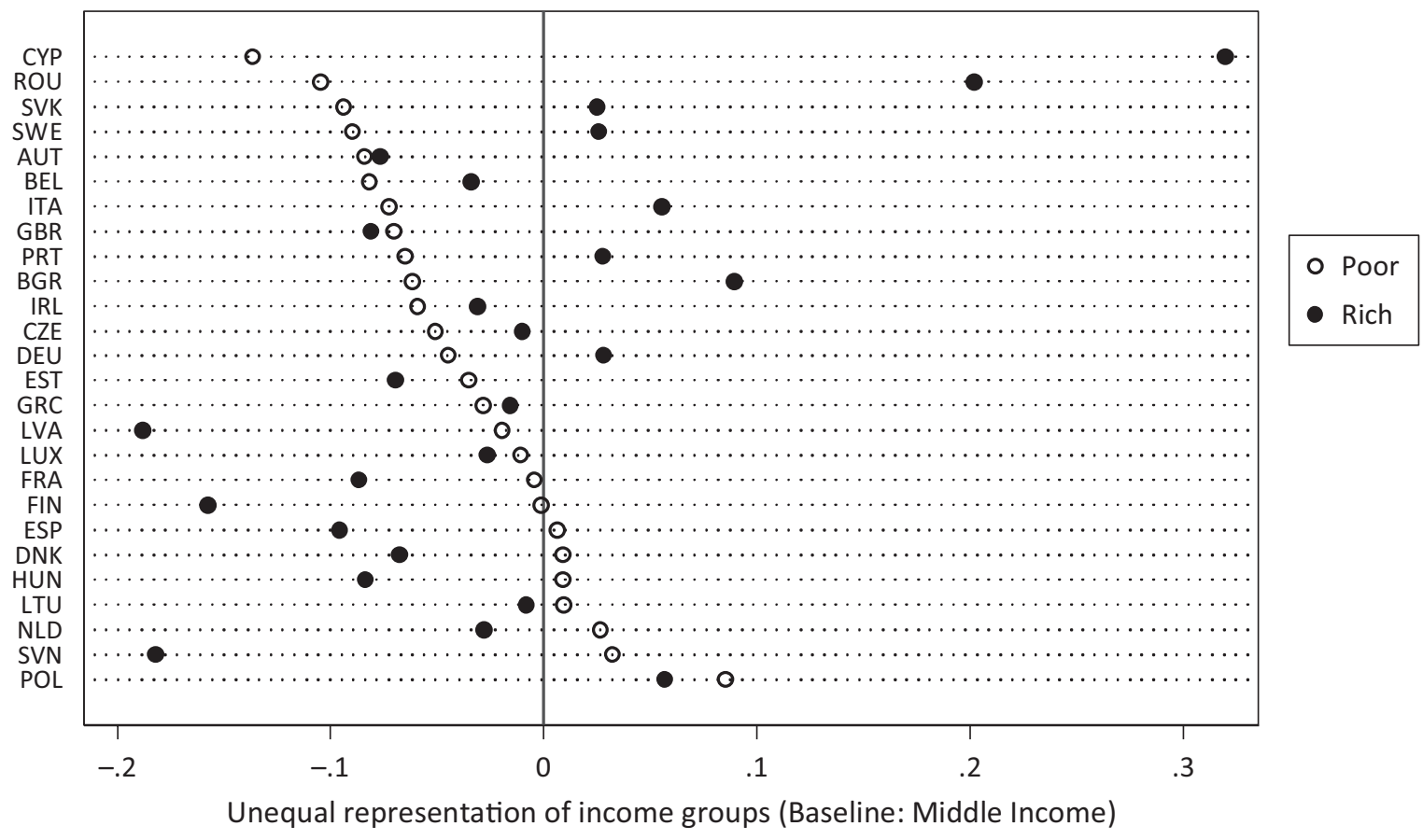

Figure 2. Unequal representation: Congruence of income groups across member states with the CoG of the Council.

in Denmark) or even, as in the case of Poland, better represented. For the rich, by contrast, there is no clear pattern. In other words, while the position of the Council systematically differs from the poor in the majority of EU member states, the CoG of the Council does not lead to systematic overrepresentation of the rich.

Table 1. Multilevel regression of individual-level congruence with the CoG of the Council.

\begin{tabular}{lcc}
\hline & \multicolumn{2}{c}{ Model 1 } \\
\cline { 2 - 3 } & B & S.E. \\
\hline Low income & -0.04 & $0.02^{*}$ \\
High income & -0.02 & 0.03 \\
Year & -0.02 & $0.00^{*}$ \\
Constant & 31.33 & $2.39^{*}$ \\
Random terms & & \\
Variance (countries) & 0.24 & 0.03 \\
Variance (individuals) & 1.37 & 0.00 \\
Variance (low income) & 0.06 & 0.02 \\
Variance (high income) & 0.12 & 0.02 \\
N (countries) & \multicolumn{2}{c}{$140316(26)$} \\
Log Likelihood & \multicolumn{2}{c}{.243588 } \\
\hline
\end{tabular}

Note: ${ }^{*} p<0.5$.

This picture is also visible in Table 1 (from which Figure 2 was produced), which shows the results of a multilevel analysis (for a similar approach, see Giger et al., 2012). It becomes evident that, while there is a statistically significant underrepresentation of the poor in the Council, there is no significant overrepresentation of the rich. In substantive terms this means that the ideological position of the poor is systematically neglected in the Council.
At the same time, however, there is no evidence from this data that the ideological position of the wealthy is overrepresented in this major EU-level institution.

\section{Conclusions}

Many centuries ago, Aristotle criticized democracy for embodying the rule of the poor and oligarchy for serving only the wealthy. Although much ink has been spilt on the EU's democratic deficits, no study has inquired into the unequal representation of income groups in EU-level institutions. The EU's complex system of multilevel transnational governance may be easier to navigate for those who have the necessary resources to do so, including knowledge and money for example, than for those who do not. The poor's unequal representation at EU level could be due, amongst other things, to their limited participation both in European elections that affect the composition of the EP and in national-level elections that affect the composition of the Council. By focusing on specific income groups our study constitutes a pioneering empirical examination of the ideological congruence (left-right) of EU institutions (i.e., the EP and the Council) with the publics for whom they make policy. By examining unequal representation on the left-right dimension of political conflict (both within the EU-wide citizenry and within national-territorial constituencies), our study also extends previous inquiries of representation on European integration in the Council (Hagemann et al., 2017), as well as work on the Council's political CoG (Manow \& Döring, 2008).

Does the EU system approximate more to a democracy or an oligarchy in its representativeness of citizens? While our research shows the EU is not an oligarchy that 
systematically over-represents the wealthy, nor does our data reflect Aristotle's fears about the poor dominating in democracy. This conclusion is based on an examination of whether the EU Council and the EP, as the major political decision-making institutions of the EU, exhibit any bias towards a specific income group, i.e., the poor or the rich. We found that both institutions tend to be positioned to the right of both rich and poor citizens, albeit closer to the rich. We then looked more closely at the Council, examining the income groups clustered in member states. On the basis of this data analyzed here we further found that while there is a systematic underrepresentation of the poor in these EU institutions there is no systematic overrepresentation of the rich. These findings complement comparative studies that have focused on the national level of governance and demonstrated a systematic underrepresentation of middle- and low-income citizens both by party systems and governments in Europe (Giger et al., 2012; Rosset et al., 2013).

These findings have important implications for our understanding of representation in the multilevel system of the EU. While it seems impossible to adequately assess the quality of democratic representation in EU member states without taking into account the extent to which citizens' views and preferences are made present at EU level, the literature has continued to neglect addressing the question of how specific social groups are represented by EU institutions (e.g., groups such as women, see Kantola and Agustín, 2019, and the poor). With the EU becoming increasingly influential in an ever-growing number of policy areas, including the fiscal policies of its member states, questions regarding the unequal representation of specific social groups can no longer be disregarded by scholars of multi-level politics.

Against this background, the following two interrelated questions arise. First, to what extent do our findings hold beyond the period of our investigation of 20002012 ? In the last years covered by our study, the Council's CoG seemed to be moving further away from all income groups, though its distance from the poor was greater. It remains to be seen whether this picture has deteriorated or improved in the intervening years, particularly given the austerity policies pursued across the EU. Second, to what extent would the picture painted in this study of broad ideological (left-right) preferences be similar, better, or worse if we also looked at specific issue dimensions? This question is pertinent given the increasing politicization of the EU dimension of political conflict that ensued from the Eurozone crisis that followed the 2008 global financial crisis, the migration crisis in the summer of 2015, and the Brexit saga that started in the mid-2016, in addition to the larger issue of immigration. Earlier work has found that, in general, the quality of representation is better in terms of left vs right ideological preferences, i.e., the main dimension of conflict in European politics, but worse in terms of cultural and European integration dimensions (Costello et al., 2012). National-level research on representation and congru- ence is moving towards the study of single-issue dimensions (see, for example, Rasmussen, Reher, \& Toshkov, 2019; Stecker \& Tausendpfund, 2016) and some first attempts have been made to study unequal representation across issue-dimensions (e.g., Rosset \& Stecker, 2019). Future work on EU-level representation should thus also go beyond the general left-right dimension to examine the EU institutions' congruence with income groups on key policy issues of concern, such as European integration, immigration, and redistribution. Given recent work suggesting that inequality is also apparent with regard to the attention given to the priorities of less affluent citizens (Traber, Hänni, Giger, \& Breunig, 2019), future work should examine the extent to which primary concerns of poor EU citizens are equally or unequally considered by and represented in EU-level institutions.

\section{Acknowledgments}

The order of authors follows a reversed alphabetical order, both authors contributed equally. For insightful comments and critique, the authors want to thank two anonymous reviewers, the guest editors of this thematic issue, Daniela Braun, Martin Gross, and Berthold Rittberger, and the participants of the workshop "Beyond the Democratic Deficit: Policy Representation and Differential Responsiveness in the EU" (May 2015) that was organized by the Robert Schuman Centre for Advanced Studies/RSCAS, European University Institute, Florence, and coordinated by Brigid Laffan, RSCAS, together with Christopher Williams, University of Arkansas at Little Rock, and Zoe Lefkofridi, University of Salzburg (both then were Jean Monnet Fellows at the RSCAS).

\section{Conflict of Interests}

The authors declare they have no conflict of interests.

\section{Supplementary Material}

Supplementary material for this article is available online in a format provided by the authors (unedited).

\section{References}

Alexandrova, P., Rasmussen, A., \& Toshkov, D. (2016). Agenda responsiveness in the European Council: Public priorities, policy problems and political attention. West European Politics, 39(4), 605-627.

Bakker, R., de Vries, C., Edwards, E., Hooghe, L., Jolly, S., Marks, G., . . V Vachudova, M. A. (2015). Measuring party positions in Europe: The Chapel Hill Expert Survey trend file, 1999-2010. Party Politics, 21(1), 143-152.

Bartels, L. M. (2008). Unequal democracy: The political economy of the new gilded age. Princeton, NJ: Princeton University Press.

Beckfield, J. (2006). European integration and income 
inequality. American Sociological Review, 71(6), 964-985.

Benoit, K., \& Laver, M. (2006). Party policy in modern democracies. London: Routledge.

Braun, D., Hutter, S., \& Kerscher, A. (2016). What type of Europe? The salience of polity and policy issues in European Parliament elections. European Union Politics, 17(4), 570-592.

Braun, D., \& Tausendpfund, M. (2019). Politisches Wissen und Europawahlen [Political knowledge and European elections]. In B. Westle \& M. Tausendpfund (Eds.), Politisches Wissen [Political knowledge] (pp. 207-236). Wiesbaden: Springer VS.

Costello, R., Thomassen, J., \& Rosema, M. (2012). European Parliament elections and political representation: Policy congruence between voters and parties. West European Politics, 35(6), 1226-1248.

de Vries, C. E. (2007). Sleeping giant: Fact or fairytale? How European integration affects national elections. European Union Politics, 8(3), 363-385.

Donnelly, M., \& Lefkofridi, Z. (2014). Economic and political inequality in modern democracies: Differential responsiveness to the policy preferences of economic classes (MWP Red Number Series 2014/13). Fiesole: European University Institute.

Elsässer, L., Hense, S., \& Schäfer, A. (2017). 'Dem Deutschen Volke'? Die Ungleiche Responsivität Des Bundestags [In the name of the German people? The unequal responsiveness of the German parliament]. Zeitschrift für Politikwissenschaft, 27(2), 161-180.

European Social Survey. (2002-2016). European Social Survey rounds 1-8. Retrieved from https:// www.europeansocialsurvey.org/data/conditions_of _use.html

Flavin, P. (2012). Income inequality and policy representation in the American states. American Politics Research, 40(1), 29-59.

Fligstein, N. (2008). Euroclash: The EU, European identity, and the future of Europe. Oxford: Oxford University Press.

Gallego, A. (2007). Unequal political participation in Europe. International Journal of Sociology, 37(4), 10-25.

Gallego, A. (2015). Unequal political participation worldwide. New York, NY: Cambridge University Press.

Giger, N., Rosset, J., \& Bernauer, J. (2012). The poor political representation of the poor in a comparative perspective. Representation, 48(1), 47-61.

Gilens, M. (2005). Inequality and democratic responsiveness. Public Opinion Quarterly, 69(5), 778-796.

Gilens, M. (2012). Affluence and influence: Economic inequality and political power in America. Princeton, NJ: Princeton University Press.

Gilens, M., \& Page, B. I. (2014). Testing theories of American politics: Elites, interest groups, and average citizens. Perspectives on Politics, 12(3), 564-581.

Golder, M., \& Stramski, J. (2010). Ideological congruence and electoral institutions: Conceptualization and measurement. American Journal of Political Science, 54(1), 90-106.

Gross, D. A., \& Sigelman, L. (1984). Comparing party systems: A multidimensional approach. Comparative Politics, 16(4), 463-79.

Hagemann, S., Hobolt, S. B., \& Wratil, C. (2017). Government responsiveness in the European Union: Evidence from Council voting. Comparative Political Studies, 50(6), 850-876.

Kantola, J., \& Agustín, L. R. (2019). Gendering the representative work of the European Parliament: A political analysis of women MEP's perceptions of gender equality in party groups. JCMS: Journal of Common Market Studies, 57(4), 768-786.

Kelly, N. J., \& Enns, P. K. (2010). Inequality and the dynamics of public opinion: The self-reinforcing link between economic inequality and mass preferences. American Journal of Political Science, 54(4), 855-870.

Kriesi, H., Grande, E., Lachat, R., Dolezal, M., Bornschier, S., \& Frey, T. (2006). Globalization and the transformation of the national political space: Six European countries compared. European Journal of Political Research, 45(6), 921-956.

Lefkofridi, Z. (in press). Opinion-policy congruence. In R. Rohrschneider \& J. Thomassen (Eds.), Oxford handbook of political representation in liberal democracies. Oxford: Oxford University Press.

Lefkofridi, Z. (2020). Competition in the European arena: How the rules of the game help nationalists gain. Politics and Governance, 8(1), 41-49.

Lefkofridi, Z., Giger, N., \& Kissau, K. (2012). Inequality and representation in Europe. Representation, 48(1), 1-148.

Lefkofridi, Z., \& Katsanidou, A. (2014). Multilevel representation in the European Parliament. European Union Politics, 15(1), 108-131.

Lefkofridi, Z., \& Katsanidou, A. (2018). A step closer to a transnational party system? Competition and coherence in the 2009 and 2014 European Parliament. JCMS: Journal of Common Market Studies, 56(6), 1462-1482.

Lefkofridi, Z., \& Kritzinger, S. (2008). Battles fought in the EP arena: Developments in national parties' euromanifestos. Österreichische Zeitschrift für Politikwissenschaft, 37(3), 273-296.

Lijphart, A. (1997). Unequal participation: Democracy's unresolved dilemma. American Political Science Review, 91(1), 1-14.

Lindvall, J. (2014). The electoral consequences of two great crises. European Journal of Political Research, 53(4), 747-765.

Mair, P., \& Thomassen, J. (2010). Political representation and government in the European Union. Journal of European Public Policy, 17(1), 20-35.

Manow, P., \& Döring, H. (2008). Electoral and mechanical causes of divided government in the European Union. Comparative Political Studies, 41(10), 1349-1370.

Mansbridge, J. (2009). A 'selection model' of political 
representation. Journal of Political Philosophy, 17(4), 369-398.

Mattila, M. (2003). Why bother? Determinants of turnout in the European elections. Electoral Studies, 22(3), 449-468.

Mattila, M., \& Raunio, T. (2012). Drifting further apart: National parties and their electorates on the EU Dimension. West European Politics, 35(3), 589-606.

Moschovis, B. (1989). Aristotelous Politika (I-II) [Aristotle's Politics (Vols. I-II)]. Athens: Nomiki Bibliothiki.

Persson, M., \& Gilljam, M. (2019). Who got what they wanted? The opinion-policy link in Sweden 1956-2014. Unpublished manuscript.

Peters, Y., \& Ensink, S. J. (2015). Differential responsiveness in Europe: The effects of preference difference and electoral participation. West European Politics, 38(3), 577-600.

Pitkin, H. F. (1967). The concept of representation. Berkeley, CA: University of California Press.

Rasmussen, A., Reher, S., \& Toshkov, D. (2019). The opinion-policy nexus in Europe and the role of political institutions. European Journal of Political Research, 58(2), 412-434.

Rohrschneider, R., \& Whitefield, S. (2012). The strain of representation: How parties represent diverse voters in Western and Eastern Europe. Oxford: Oxford University Press.

Rosset, J., Giger, N., \& Bernauer, J. (2013). More money, fewer problems? Cross-level effects of economic deprivation on political representation. West European Politics, 36(4), 817-835.

Rosset, J., \& Pontusson, J. (2014). The impact of the great recession on public preferences for redistribution in Western Europe. Paper presented at the Annual Meeting of the American Political Science Association, Washington, DC, USA.

Rosset, J., \& Stecker, C. (2019). How well are citizens represented by their governments? Issue congruence and inequality in Europe. European Political Science Review, 11(2), 1-16.
Rueda, D., \& Pontusson, J. (2010). Individual preferences for redistribution in Western Europe: Selfinterest, political articulation, altruism and identity. Unpublished manuscript. Retrieved from https:// leitner.yale.edu/sites/default/files/files/resources/ papers/RuedaYale2010.pdf

Schäfer, A., \& Schwander, H. (2019). 'Don't play if you can't win': Does economic inequality undermine political equality? European Political Science Review, 11(3), 395-413.

Schakel, W. (2019). Unequal policy responsiveness in the Netherlands. Socio-Economic Review, 1-21. https:// doi.org/10.1093/ser/mwz018

Schakel, W., \& Hakhverdian, A. (2018). Ideological congruence and socio-economic inequality. European Political Science Review, 10(3), 441-465.

Schmitt, H., \& Thomassen, J. (1999). Political representation and legitimacy in the European Union. Oxford: Oxford University Press.

Soroka, S. N., \& Wlezien, C. (2008). On the limits to inequality in representation. PS: Political Science \& Politics, 41(2), 319-327.

Stecker, C., \& Tausendpfund, M. (2016). Multidimensional government-citizen congruence and satisfaction with democracy. European Journal of Political Research, 55(3), 492-511.

Thomassen, J., \& Schmitt, H. (1997). Policy representation. European Journal of Political Research, 32(2), 165-184.

Traber, D., Hänni, M., Giger, N., \& Breunig, C. (2019). What poor and rich consider as important and how this matters for representation (Unequal Democracies Working Paper No. 9). Geneva: University of Geneva. Retrieved from https://unequal democracies.unige.ch/files/9715/6257/0921/ wp9.pdf

Ura, J. D., \& Ellis, C. R. (2008). Income, preferences, and the dynamics of policy responsiveness. PS: Political Science \& Politics, 41(2), 785-794.

\section{About the Authors}

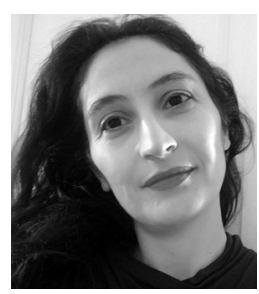

Zoe Lefkofridi is Associate Professor of Comparative Politics at the Department of Political Science and Sociology, and fellow at the Salzburg Center of European Studies (SCEUS), at the University of Salzburg. Zoe works on democracy, European integration, and inequality in political representation, in particular gender and its interplay with other forms of inequality. Her academic work appears in leading international peer reviewed outlets, such as West European Politics, European Union Politics, and Politics \& Gender.

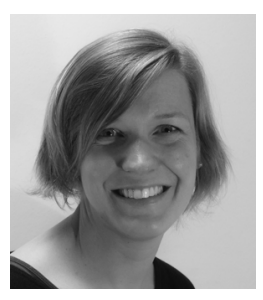

Nathalie Giger works as Associate Professor of Comparative Political Behaviour at the University of Geneva. Her research focuses on the linkages between citizens and political elites with a special focus on question of question of inequality. Her work has appeared in the American Journal of Political Science, Comparative Political Studies, and the European Journal of Political Research, among others. 